\title{
Analysis on the Marketing Strategy of Cross Border C2C Cosmetics Based on Taobao's Global Purchase Platform
}

\author{
Xiaowei Zhu ${ }^{1,2}$ and $\mathrm{Xi} \mathrm{Cao}^{1}$ \\ ${ }^{1}$ Wuhan Technology and Business University, China, Hubei, Wuhan, 430065 \\ ${ }^{2}$ Hubei Business Service Development Research Center, China, Hubei, Wuhan, 430065
}

Keywords: Cross-border electricity business; Cross-border logistics; Cosmetics marketing

\begin{abstract}
Cross border $\mathrm{C} 2 \mathrm{C}$ is an important branch of cross-border electricity business. This form of cross national boundaries individual trade with the help of the Internet platform has been a "new blue ocean" after the mobile electricity suppliers, which fast lead the wave of national Entrepreneurship. Taobao as the most successful C2C large shopping site in the current domestic electricity business, its promotion of a platform for overseas markets "the global purchase" gets the widespread concern of Internet users. This article starts from the current situation of cross-border C2C e-commerce, with Taobao network "global purchase" platform as the research object, to analyze the cosmetics purchasing market and marketing strategy.
\end{abstract}

\section{Introduction}

In the big background of the development of domestic living standards and the rapid rise of the e-commerce industry, the local commodity has not met the growing diversity of consumer demand. With the Chinese government to actively promote the "bringing in" and "going out" policy, many famous foreign brands have to seize the domestic market, but because of high tariffs and circulation tax, resulting in into the domestic and overseas high commodity prices. In addition, the majority of the domestic people lack in-depth understanding of overseas brands, which seriously impacts the development of cross-border trade.

The e-commerce transaction mode, led by Taobao, has completely changed the predicament, which has opened a new way to the overseas market. Originally, a part of the students abroad and the senior white-collars who are often to and from every country groups aimed at overseas purchasing opportunities, gradually evolved into an acquaintance as the main form of cross-border trade. With the progress of Internet technology and the development of international logistics, cross-border $\mathrm{C} 2 \mathrm{C}$ has become the synonymous of overseas purchasing under the new norm.

\section{Taobao's Global Overview and the Status Quo of the Cosmetics Market}

The Operation Mod of Global Purchase Platform. Global purchase platform are currently mainly two operating systems of private purchasing and the official website of the direct purchase. Individual online shop is the main body of the cross-border $\mathrm{C} 2 \mathrm{C}$ operating system of the global purchase. The owner is generally overseas chicness or students studying abroad who stably live in foreign countries, as long as the opening of the Taobao account, you will be able to set up their own online shop to provide overseas purchasing services for domestic users with free of charge on the global platform. Purchasing business will released foreign goods information to their shop, with Ali Wangwang, such as instant messaging software to communicate Online with customers having purchase intention. After an order is reached, goods Purchased by the seller in a foreign entity shop, through cross-border mail or by entrainment to private goods, are transported to the domestic agency, then the domestic third party logistics company forwarded to all buyers. As this model involves tax evasion or part of the tax evasion, with low transportation cost when goods are in transit, it's easy to be inspected even have the risk of check, So there are many problems of individual purchasing. 
Opportunities for Cross-Border Cosmetics Market. Overseas brands have price and quality advantages. Domestic cosmetics market restricted by funds and R \& D technology, less product category brand younger, go in the low-end market, while the high-end market in the country has not yet formed the scale. The development of cosmetics market in developed countries is mature, and the types of products are comprehensive; with reduction equipment modernization, $\mathrm{R} \& \mathrm{D}$ update fast; with strict quality requirements and appropriate price, a long history and accumulated a solid brand advertising social recognition, a long history of brand and advertising accumulated solid social recognition.

The Expansion of Online Shopping Groups Has Brought Demand Growth. With the Internet technology to promote the transformation of traditional industries, cross-border electricity business has become a new economic growth point. The generation after 80s and 90s as the main sectors of society in which women are the main force to promote the consumption of cosmetics, Their awareness of overseas brands to improve, the focus of the goods purchase also tend to good quality, reasonable price. This brings the growing domestic demand for foreign products to buy cheap and inexpensive, which is more conducive to the rapid development of cross-border cosmetics E-commerce.

Advances in Information Technology Promote the Rise of Cross-Border Electricity Suppliers. The popular of WeChat, micro-blog, micro shop and other new social media provides a channel for the promotion and promotion of products for overseas purchasing. Not only the online shop, micro-blog, WeChat with a strong user base, mobile clients can reach several billion per day. Especially the cosmetics market has distinct characteristics of the cluster, the girls loving beauty use virtual space in the network, in the community, forum, micro channel group to share a large number of overseas sales of product information, to teach each other, purchase experience, drying out rich product photographs.

The Development of Transportation Drives the Change of Cross Border Logistics. Fast, smooth of logistics services become one of the important reasons for the rapid rise of cross-border electricity suppliers trading model. The major international logistics model is mainly air transport and water transport. Air transport with fast speed, high security, but the cost is large, less cargo, suitable for the transport of fresh and fast food; Waterway transport with along cycle and easy to be influenced by natural factors, is suitable for large transport volume, not easily damaged goods. However, these two kinds of international logistics model is not suitable for goods of small size, easy loss such as cosmetics. Nowadays logistics and business facilities following up, several avenues of direct mail, courier, bonded warehouse, guarantee the goods in transit safety, received the goods time more and more short, purchasing more humane.

\section{Sales Strategy Introduction of Cross Border C2C Cosmetics}

Product Strategies. Different from the domestic electricity suppliers of goods serious homogenization phenomenon, the majority of cross-border purchasing companies have their own clear product positioning. A product in different markets have different consumer groups, purchasing. Purchasing business to enter the market need to do an adequate market research in the early days, combine with their own strength to determine the target market and the corresponding audience, carefully study the change of the demand of consumer preference and ideology, choose targeted products and adjust the brand strategy.

Price Strategies. Cross border purchasing cosmetics in terms of price advantage is reflected in that the difference price of cosmetics between in source area and in domestic counter is too large. Taking Hong Kong and Macao as a reference, the average price of cosmetics counters is only about ten percent off of the mainland counter, and then through the exchange rate conversion, only twenty percent off price of domestic counter can buy the same amount of products. France, the United Kingdom and other cosmetics originating in the region, the price is cheaper, through the exchange rate down, and sometimes the price can be as low as half of the domestic counter price. Official site 
will hold regular members such as the sale of promotional activities, such as the case of holidays, the clearance at the end of the season, plus income gifts, the price will have more preferential. In this case, the purchasing agents can often use the most affordable price to buy high-quality, innovative products, even in accordance with the original price of $10 \%$ to collect service fees, but also a lot lower than the domestic price.

Channel Strategies. New media operators also for the owner must be supporting the use of channel strategy. Foreign popular social software is twitter, Facebook, which cannot be used in mainland China, but in the mainland popular social software is microblogging, letters which is similar to the Twitter and face book. Purchasing only need to download the mobile app, register the account on the mobile terminal, can have its own exclusive social networking platform, which is convenient for mainland users timely communication. The seller can anytime, anywhere online to communicate with fans, establishes a connection with the customer's emotional. New media users are mostly young people who have strong accept ability to new things. a product by forwarding a circle of friends, has a fast propagation speed and involves a wide range, like micro-blog's popular masters, update a message, the moment will be able to have thousands of comments reply, marketing capabilities can be seen.

Promotion Strategy. Global purchase on every day, constantly updated global hot commodity. How to be unique in the hundreds of thousands of goods, the design of a novel and the public goods title in line with the tastes are important. Cosmetics as women are keen to buy consumer goods, sellers are often combined with current trends, will bind star and overseas TV dramas to publicize. Young women because the pursuit of idol or infected by a unit hit characters modeling, are easy to follow suit imitate, more willing to accept related search term in the recommended selling models. For example, a drama "you who come from the stars" has swept through Asia in the big screen, main female Qian Song whose Yi iope44 and forever pink lipstick become hot search many girls beauty. At the same time, a lot of purchasing business have introduced thousands of Song Yi same commodity, with various models of brand clothes, bags and cosmetics in the global share of rage.

\section{Problems and Improvement of Cosmetic Marketing Strategy of Cross Border C2C}

Product Positioning Is not Clear. Many cross-border sellers just contacting without a detailed understanding of purchasing the business, just felt cosmetics market profits in a large space, blindly follow the general purchasing. If purchasing business in New Zealand such agricultural economy, purchasing maternal and infant milk powder will than purchasing cosmetics more promising; if the purchasing business in France such fashion developed countries, purchasing luxury goods is higher margins than purchasing cosmetics more.

Taking products as the starting point and taking the market as orient, to solve this positioning is not a reasonable marketing strategy. What type of the brands, what kind of consumer groups suitable for, which regions suitable for the target market in china, sources from which to get, how to ensure that the supply chain is not out of line, these problems need to take into account when a shop set up in the early stages of product positioning, as long as there is a clear direction, the operator will be more effective.

The Off-season Sales after Price War. Cosmetics as long cycle goods, In the online shopping there being a clear sales season and off-season, buyers will be based on changes in the market to determine the purchase intentions. For example, Taobao in double eleven such a large-scale shopping carnival, major brands in discount promotions, consumers will pick this time burst buy stockpile. However, after a fierce spike, a lot of shops are often caught in the off-season and some sellers feel that the season has passed, and then put more, less than the corresponding return. It is no longer as active as the busy season of the store, resulting in the original business is also reduced. Once the shop long time No one shows any interest in then soon lost PPC opportunity.

So how for the seller improve the low season operating unfavorable situation? First, the seller should adjust the mentality, to seize the needs of consumers, to provide more quality products; In 
addition, appropriately decorating shop and optimizing the product catalog give visitors a fresh visual experience, but also increase the popularity of the shop.

Homogeneous Search Channels. Setting search keywords is important, but the keywords are not only the pursuit of hot, but also to put the characteristics, the advantages and selling of the product into the title. Sometimes buyers looking at the list searched out, is just to sweep, then the title which is too long or too short will affect the customer mentality. For example cosmetic shop, commodity name set to "the United States purchasing genuine Revlon liquid foundation", there is only "Revlon" and "fluid foundation" as the key word, appropriate to add some product characteristics such as Moisturizing without bleaching, Sweat resistance lasting and that buyers can in the shortest possible time find your product key attributes and remember. If you blindly borrow other seller's similar commodity names, so that after entering the classification of goods by luck will be found in the buyer, or even simply search.

After do a good job in the title of the goods, we cannot ignore the details of the baby. Purchasing business involved in international trade, there are opaque, if there is no true picture of fully reflect the product, raw material, place of origin, packaging, production date and method of use, buyers will not be able to get a detailed product information. It still takes time to consult the seller, psychological did not meet the strong desire to buy, is likely to will result in the loss of customers.

\section{Research Conclusions and Recommendations}

Although cross-border $\mathrm{C} 2 \mathrm{C}$ become one of the promising industries, the $\mathrm{C} 2 \mathrm{C}$ is still in the early stages of development, industry personnel constitute is a complex and fragmented and marketing model is not mature. Under the environment that the country has not yet introduced the relevant management measures, the market appears to be a number of contradictions to be resolved. With the current situation of cross-border $\mathrm{C} 2 \mathrm{C}$ cosmetics marketing, starting from the four positions of the government, consumers, the global purchase platform, raise a number of recommendations

Government Strengthens Industry Regulation, Standardizes Purchasing Market. Overseas purchasing is a new service industry, the government should introduce relevant laws and regulations, to intensify supervision, strengthen cooperation of supervision and e-commerce trading platform, to avoid the process of overseas purchasing in the process of bilateral friction. Establishing the integrity system of overseas purchasing, Technical security protection is giving for sensitive and personal data involved in online transactions. Building online shopping dispute processing system, consumers can make complaints and rights through this system. Cosmetics is special for involving hygienism; , health and other factors, for the purchase of such goods, should be effectively controlled, the import and sales aspects of the implementation of administrative licensing system

Consumers Should Strengthen Risk Prevention and Awareness of Rights. Overseas purchasing risk always exists, but consumers should enhance the awareness of risk prevention. When choosing purchasing business, to avoid straying into private phishing web site, try to in the formal large commercial shopping platform to find sellers; for information on goods provided by the seller, know the price and quality of the product and prepare for in advance; Be familiar with the brand's small ticket and invoice format the in foreign counter; When going the transaction payment, consumers choose third party guarantee payment; when receiving the goods, carefully check the information and after verification and then confirm the payment. If, in the course of transport of goods, receive a suspected personal information, account numbers, passwords and others, first contact with the seller, after the confirmation and then reply. In addition, when meeting seller selling fake and a single malicious fraud cheat, we should pay attention to the preservation of relevant evidence, and timely response to the prosecutor's Office.

Taobao's Global Purchasing Platform should Increase the Power of Supervision and Review for Individual Purchasing. The online shop with a lower threshold, more and more overseas students, occupation buyers join cross-border purchasing industry. Under the situation that the internal competition has further aggravated, the homogenization of goods, phenomenon of 
storing up fake goods to make a good bargain seriously reduce hoarding and profiteering customer trust of overseas purchasing. Taobao should develop more stringent rules for the seller's access to the global purchasing platform, Not only requires the seller in global purchasing to provide the certificate of Hong Kong, Macao and Taiwan overseas direct delivery, including counter purchasing a small ticket, the Customs issued a valid certificate, brand agency authorization, etc. Once the seller illegal operation behavior must be severely punished, depending on the seriousness and take store credit points even forced closed shop punishment. At the same time the construction of the channels of complaints to encourage consumers to report fraud businesses, to safeguard their legitimate rights and interests.

Cross Border Purchasing business should Be Good Faith Management, Reasonable Adjustment of Marketing Strategy. First of all, the purchase should correct professional ethics, to ensure that the regular channels for the sale of goods which will be the long-term recognition of customer groups. On the other hand, through multi cooperation with online and offline ,online promotion and consumer communication, clearly describes the performance of the product, reduce the buyer's sense of insecurity arising from overseas; Strengthening cooperation with domestic logistics enterprises under the line, the process of cross-border transportation is far away, and the transportation process is complex. Once, the goods such as cosmetics because of the damage caused by the logistics, squeezed issue influence selling. The seller should promptly contact the Logistics Company and domestic customer service, be responsible for handling customer service of commodity exchange.

\section{Acknowledgements}

Fund Project: Hubei Provincial Collaborative Innovation Center for Modern logistics and business (Project No.2011A201307)

Fund Project: MOE (Ministry of Education in China) Project of Humanities and Social Sciences (Project No.14YJCZH154)

Funding team: Wuhan Technology and Business University Academic Team (Project No. XSTD2015004)

\section{References}

[1] Lai Youwei,Li Guangqian, Shi Guang China's e-commerce development: Problems and Countermeasures [J]The New Economic Herald, 2015,3

[2] Fan Wenjing The development of cross-border e-commerce and the transformation of China's foreign trade model $[\mathrm{J}]$ Foreign trade and economic cooperation, 2015, 1

[3] Lv Ji An analysis of the restrictive factors in the development of electronic commerce [J] Wuhan business, 2013, 3

[4] Shi Qinbo the causes of Internet Purchasing and the problems needing attention [J] Economic Forum, 2006 (8)

[5] Fang Yingzhi in 2010, China overseas purchasing development status and industrial scale area [R] Bai Bao an enterprise network marketing research center, 2011

[6] Luo Wenli international purchasing: emerging logistics market [J] Chinese logistics and procurement, 2010 (18)

[7] Lin Bo Xu Linping Analysis of the status quo and marketing strategy of overseas purchasing cosmetics [J] Market week (theoretical study), 2012.11:45 a 48+126

[8] Problems and Countermeasures of overseas purchasing in China's network of Wu Fuhe [J] Foreign trade and economic cooperation, 2015.01:138 140 
[9] Trade and Industry Bureau of Shanghai city market Network overseas purchasing [J] Industrial and commercial management research, 2009, (07) 15-18

[10] China e-commerce research center in the first half of 2011 China e-commerce market data monitoring report [R] Hangzhou: China Electronic Commerce Research Center, 2011-08-01 